\title{
Effect of addition of plant extracts on the durability and sensory properties of oat flake cookies
}

\author{
Anna Zbikowska ${ }^{1} \cdot$ Mariola Kozlowska $^{1} \cdot$ Andrzej Poltorak $^{2} \cdot$ Malgorzata Kowalska $^{3} \cdot$ Jaroslawa Rutkowska $^{2}$. \\ Milena Kupiec ${ }^{1}$
}

Received: 11 June 2017 / Accepted: 13 April 2018/Published online: 23 April 2018

(c) The Author(s) 2018

\begin{abstract}
Fragile cookies are one of the most popular high-fat cereal products. Products of this type with added oat flakes may be labeled with a nutrition claim and may be included in functional foods. Fat from oat flakes and which is a recipe ingredient of cookies undergoes degradation during storage which leads to the formation of harmful oxidation products and sensory changes in products. The aim of this study was to determine the effect of green tea extracts (GT), blackcurrant (BC) seeds and nettles $(\mathrm{N})$ on the rate of fat degradation in cookies with oat flakes and their sensory properties. In this work, the antioxidant effect of natural extracts antioxidant on oxidative stability of fat extracted from cookies was evaluated by differential scanning calorimetry (DSC) and by peroxide value, anisidine value and specific UV extinctions ( $K$ value). Moreover, cookies were subjected to sensory analysis and to instrumental measurements of color changes. The extracts used in the study had an influence on the rate of fat oxidation changes in cookies after baking and also during 3 months of storage. The most effective fat degradation inhibitor was the extract with GT in $1 \%$ addition, while the most unfavorable change was observed in fat with the lowest addition of $\mathrm{N}$ extract $(0.5 \%)$. It was observed that the applied plant extracts did not significantly reduce the sensory properties of the products. The most desirable products were the cookies with $1 \%$ GT extract and those with the highest proportion of blackcurrant seed extract $(1.5 \%)$.
\end{abstract}

Keywords Oat flake cookies · Plant antioxidants $\cdot$ Oxidative stability $\cdot$ DSC $\cdot$ Sensory analysis

\section{Introduction}

Scientists, consumers and food manufacturers are increasingly aware of the importance of food products in maintenance of good health (called functional or therapeutic

Anna Zbikowska

anna_zbikowska@sggw.pl

Malgorzata Kowalska

mkowalska7@vp.pl

1 Faculty of Food Sciences, Warsaw University of Life Sciences - SGGW, Nowoursynowska 159C, 02-787 Warsaw, Poland

2 Faculty of Human Nutrition and Consumer Sciences, Warsaw University of Life Sciences -SGGW, Nowoursynowska 159C, 02-787 Warsaw, Poland

3 Faculty of Material Science, Technology and Design, Kazimierz Pulaski University of Technology and Humanities in Radom, Chrobrego 27, 26-600 Radom, Poland foods) [1]. By adding to typical cookies biologically active ingredients (nutraceutics) rich in undesirable dietary saturated fatty acids (SFA) as well as trans isomers [2], such as dietary fiber (DF), one can improve their nutritional value, so that they become included within functional foods. DF is a very important food ingredient, because its high proportion in the diet plays a major role in prevention of civilization diseases such as diabetes, hypertension, cardiovascular diseases, obesity, certain cancers and constipation [3-6].

A rich source of DF is oats, which contain at the same time much more fat, rich in polyunsaturated fatty acids, than other cereals [7]. Such fat is unstable, because of the rapid oxidation process. Thus, oat products, such as oat flakes, made into cereal products such as cookies, suffer reduced durability [8].

The effect of lipid oxidation is formation of unwanted flavors and odors that shorten the shelf life of food. At the same time, the nutritional value and safety of food products 
decrease as a consequence of the formation of harmful oxidation products, which are associated with a number of degenerative processes and disorders, such as inflammation, cardiovascular diseases and cancer [9]. Adding antioxidants to the food is an effective preventive element for the lipid oxidation process. Concerns about the effects of synthetic additives generate the need to find antioxidants of natural origin. However, their applicability must be checked beforehand, including their impact on the final product, particularly on its sensory characteristics [10]. Green tea, nettles or black currant seeds, for example, may have protective effect on fats in bakery products. The literature includes reports of their antioxidant properties. The antioxidant activity of green tea in food is associated with the presence of catechins [11]. Flavonoids, especially phenolic compounds, are present in nettles [12]. Also blackcurrant seeds (waste from juice production) can be a source of natural antioxidants, and their extracts have antioxidant effects in oil [13].

The aim of this study was to determine the effect of plant extracts obtained from green tea, blackcurrant seeds and nettles on the rate of fat degradation in cookies with oat flakes and on their sensory properties.

\section{Experimental}

\section{Materials and experiments}

The study material consisted of oat flake cookies and extracted fat from them. Based on preliminary studies and information in the scientific literature on the antioxidant efficacy of green tea extract [10], oat flake cookies with $1 \%$ green tea extract were accepted as a control sample in this study.

Dough ingredients: oat flakes-33\% (Kupiec sp. z. o.o., Poland), shortening-15\% (AarhusKarlshamns, Sweden); also wheat flour $(17 \%)$, sugar (15\%), milk powder (5\%) and eggs $(15 \%)$, were purchased locally.

Aqueous plant extracts in the form of lyophilisate (Goldmann HSH Sp. z o.o.) were used in the following doses: green tea $1 \%$, blackcurrant seeds and nettles in the amounts $0.5,1.0$ and $1.5 \%$. The formula for preparing cookies contains as much as $33 \%$ of oat flakes (with a fiber content of $9.5 \%$ ), which allows them to be classified as functional food. In accordance with the provisions in force, fiber-rich foods (at least $3 \mathrm{~g} / 100 \mathrm{~g}$ serving) may include nutrition and health claims [14].

\section{Cookie preparation method}

The ingredients (shortening, sugar, milk powder and eggs) were stirred for 5 min using the Braun Multiquick kitchen processor (type 4644) to obtain a creamy texture. Then, the flour, the plant extracts and oat flakes were added. A square-shaped piece of dough with $55 \mathrm{~mm}$ sides and a thickness of $4 \mathrm{~mm}$ was baked at $170{ }^{\circ} \mathrm{C}$ for $8 \mathrm{~min}$ in the Unox convection steam oven, type XBC (Vigodarzere, Italy). Cookies were stored for 1, 2 and 3 months in carton packs at $21 \pm 2{ }^{\circ} \mathrm{C}$.

\section{Methods of fat extraction}

The lipids were extracted from cookies and from oat flakes and extraction was carried out by Folch et al.'s method [15] using a chloroform-methanol $(2: 1 \mathrm{v} / \mathrm{v})$, at room temperature. The extract was dried over $\mathrm{Na}_{2} \mathrm{SO}_{4}$.

\section{Fat analysis}

Fatty acid composition of the shortening and fat extracted from oat flakes was determined by gas chromatography according to the ISO 5508:2000 standard. The fatty acids were esterified according to ISO 5509: 2000 and applied to the column (Agilent 6890 GC System); a flame ionization detector and capillary column $(60 \mathrm{~m} \times 0.25 \mathrm{~mm}$ ID SGE BPX 70) were used. The oven temperature was 160-210 ${ }^{\circ} \mathrm{C}$, increasing at a rate of $2.5^{\circ} \mathrm{C} \mathrm{min}-1$. The carrier gas was helium, air flow rate $30 \mathrm{~mL} \mathrm{~min}^{-1}$; injector: split-splitless $240{ }^{\circ} \mathrm{C}$; detector: FID $250{ }^{\circ} \mathrm{C}$; software: HP Chemstation v. 3.11. The composition of FA was expressed as the peak area percentage of total fatty acids.

The peroxide value (PV), anisidine value (AV) and specific UV extinctions ( $K$ values) were determined in accordance with ISO standard methods (3960:2012; 6885:2008; and 3656:2011, respectively). All analyses were carried out in three replicates.

DSC measurements were taken with a DSC 820 from Mettler Toledo (Schwerzenbach, Switzerland) with air flow of $60 \mathrm{~mL} \mathrm{~min}{ }^{-1}$. The fat samples of $3.6-4.0 \mathrm{mg}$ were placed into aluminum pans and closed with lids with a hole drilled in the center in order to allow the samples to be in contact with the air stream. The aluminum reference pan as identical as possible to the sample pan was left empty. The sample and reference pans were heated linearly to $300{ }^{\circ} \mathrm{C}$ with the rates of $4,7.5,10,12.5$ and $15{ }^{\circ} \mathrm{C} \mathrm{min}{ }^{-1}$. The onset oxidation temperatures $\left(t_{\mathrm{ON}},{ }^{\circ} \mathrm{C}\right)$ were determined as the intersection of the extrapolated baseline and the tangent line of the recorded exotherms. The $t_{\mathrm{ON}}$ experimental values as a function of heating rates $(\beta)$ were directly measured and recalculated as absolute onset temperatures $\left(T_{\mathrm{ON}}, \mathrm{K}\right)$. Using the Ozawa-Flynn-Wall method and the Arrhenius equation, the kinetic parameters of the oxidation process (activation energy $E_{\mathrm{a}}$, pre-exponential factor $Z$, and induction time $\tau$ ) were calculated. The calculation 
procedures for kinetic treatment were given in a recent study [16].

The stability of the lipid fraction in the cookies was monitored during their storage for 3 months by determining: $\mathrm{PV}$ and $\mathrm{AV}$, coupling dienes and trienes, using differential scanning calorimetry (DSC).

\section{Analysis of plant extracts}

The total phenolic content was determined using the FolinCiocalteu reagent method described by Singleton and Rossi [17] with a slight modification. Briefly, $1 \mathrm{~mL}$ powdered plant extract $\left(1 \mathrm{mg} \mathrm{mL}^{-1}\right)$ was transferred into a flask and mixed with deionised water $(10 \mathrm{~mL})$. Then, Folin-Ciocalteu reagent $(0.5 \mathrm{~mL})$ was added to the mixture. After $3 \mathrm{~min}, 5 \mathrm{~mL}$ of $\mathrm{Na}_{2} \mathrm{CO}_{3}(20 \%$, w/v) solution was also added. After standing for $1 \mathrm{~h}$ at room temperature, the absorbance was measured at $765 \mathrm{~nm}$. Gallic acid was used to construct the standard curve. The total phenolic content was expressed as mg gallic acid equivalents per gram of dry extract.

Free radical scavenging activity of the powdered plant extracts was determined by the method of Gow-Chin and Hui-Yin [18] with some modification. One milliliter of $0.3 \mathrm{mM}$ freshly prepared DPPH methanol solution was mixed with $0.2 \mathrm{~mL}\left(1 \mathrm{mg} \mathrm{mL}^{-1}\right)$ of the extract and $3.8 \mathrm{~mL}$ of methanol. After standing for $10 \mathrm{~min}$ at room temperature, the absorbance at $517 \mathrm{~nm}$ was measured. Trolox was used for constructing the standard curve. The antioxidant capacity based on the DPPH-free radical scavenging ability of the extract was expressed as $\mathrm{mM}$ Trolox equivalents per gram of dry matter of extract.

The 2,2'-azinobis (3-ethylbenzothiazoline-6-sulfonic acid) diammonium salt (ABTS)-free radical scavenging activity was assayed by the method developed by Re et al. [19]. Briefly, ABTS was produced by reacting ABTS stock solution $(14 \mathrm{mM})$ with potassium persulfate $(4.9 \mathrm{mM})$ and was kept for $12-16 \mathrm{~h}$ in the dark at room temperature. For the analysis, the solution was diluted in water to the absorbance of $0.7 \pm 0.02$ at $734 \mathrm{~nm}$. Then, $40 \mu \mathrm{L}$ of plant extract and $4 \mathrm{~mL}$ of ABTS $^{\bullet+}$ working solution were mixed. After $6 \mathrm{~min}$, the absorbance of samples at $734 \mathrm{~nm}$ was recorded and compared to that of the calibrated Trolox standard. Results were expressed as $\mathrm{mM}$ Trolox equivalents per gram of dry matter of extract.

\section{Color analysis of cookies}

The color of oat flake cookies was measured using a tristimulus reflectance colorimeter (Minolta CM-3600d, Konica Minolta Sensing, Inc., Tokyo, Japan). The intensity of the color was determined by its three elements: $L *$ (whiteness, zero blackness), $a *$ (positive value-red, negative value-green), $b *$ (positive value-yellow, negative value-blue). The final result was the arithmetic mean of 12 measurements.

\section{Sensory characteristic of fragile cookies}

Sensory evaluation was performed by a trained team of 20 persons, after $24 \mathrm{~h}$ of baking.

Detailed quantitative descriptive analysis (QDA) was performed using the analytical procedure described in ISO 13299:2003. The following characteristics were specified: appearance (color, cracks on the surface of the cookies), aroma (herbal, tea, fruity, desirable), texture (hardness, fragility), taste (sweet, herbal, tea, fruity, desirable) and overall quality of samples. The obtained values were converted into numerical values on a scale of $0-10$.

\section{Statistical analysis}

The Statgraphics plus 4.0 package (Statistical Graphics Corp., USA) was used for analysis. Interpretation of results was based on Tukey's test with a significance level of $p \leq 0.05$.

\section{Results}

\section{Quality of the fatty material, fat from oat flakes and antioxidant properties of the extracts}

Fat oxidation stability of fat, its technological suitability and nutritional value depend on the composition of fatty acids [20]. The high total content of saturated FAs and FA trans isomers (77.72\%) in the applied shortening indicates a high fat oxidation resistance. The dominating FA in the shortening was palmitic acid (44.0\%) and in oat flakes was lauric acid (41.9\%) and oleic acid (34.3\%) (Table 1).

The content of primary oxidation products in the fatty material expressed in peroxide value (PV) was $0.82 \mathrm{mEqO} \mathrm{kg}{ }^{-1}$ fat. On the other hand, the PV of fat extracted from oat flakes was higher $\left(2.2 \mathrm{mEqO} \mathrm{kg}^{-1}\right.$ fat $)$ but also did not exceed the limit $\left(3 \mathrm{mEqO} \mathrm{kg}{ }^{-1}\right.$ fat $)$ determining good bakery fat quality [21]. The result of the number of secondary products of oxidation measured by $\mathrm{AV}$ in fats used for baking was 1.2, which, being below 3, proved their good quality [22]. Similarly, low values of AV (mean 2.05) were obtained in the lipids extracted from oat flakes.

The results of the total phenolic content determination and antioxidant activity of the examined plant extracts are presented in Table 1. The highest content of phenolic compounds was recorded in green tea extract followed by blackcurrant seeds and nettle extracts. In the DPPH and 
Table 1 Characteristics of fatty material (raw material), fat from oat flakes and plant extracts

\begin{tabular}{|c|c|c|c|c|c|c|c|c|c|}
\hline \multicolumn{10}{|c|}{ Fatty acids/\% } \\
\hline $8: 0$ & $10: 0$ & $12: 0$ & $14: 0$ & $16: 0$ & $18: 0$ & $18: 1$ & $18: 1$ trans & $18: 2$ & $18: 3$ \\
\hline \multicolumn{10}{|c|}{ Shortening } \\
\hline 1.73 & 1.8 & 16.9 & - & 44.0 & 4.8 & 18.4 & 0.4 & 4.1 & - \\
\hline \multicolumn{10}{|c|}{ Fat from oat flakes } \\
\hline & - & - & 0.4 & 17.3 & 1.1 & 34.3 & - & 41.9 & 1.4 \\
\hline \multicolumn{10}{|c|}{ Antioxidant activity of extracts } \\
\hline & \multicolumn{2}{|c|}{$\begin{array}{l}\text { Total phenolic content/ } \\
\text { mg GA g }{ }^{-1} \text { extract }\end{array}$} & & \multicolumn{2}{|c|}{$\begin{array}{l}\text { DPPH/ } \\
\text { mmol Trolox } g^{-1} \text { extract }\end{array}$} & \multicolumn{3}{|c|}{$\begin{array}{l}\text { ABTS/ } \\
\text { mmol Trolox } g^{-1} \text { extract }\end{array}$} & \\
\hline GT & \multicolumn{2}{|c|}{$156.06 \pm 6.10 \mathrm{c}$} & & \multicolumn{2}{|l|}{$3.12 \pm 0.10 \mathrm{c}$} & \multicolumn{3}{|c|}{$3.860 \pm 0.10 \mathrm{c}$} & \\
\hline $\mathrm{BC}$ & \multicolumn{2}{|l|}{$29.24 \pm 0.30 \mathrm{~b}$} & & \multicolumn{2}{|l|}{$0.36 \pm 0.02 b$} & \multicolumn{3}{|c|}{$0.450 \pm 0.01 b$} & \\
\hline $\mathrm{N}$ & \multicolumn{2}{|c|}{$23.74 \pm 0.20 \mathrm{a}$} & & \multicolumn{2}{|l|}{$0.068 \pm 0.00 \mathrm{a}$} & \multicolumn{3}{|c|}{$0.089 \pm 0.00 \mathrm{a}$} & \\
\hline
\end{tabular}

$G T$ green tea, $B C$ blackcurrant seed, $N$ nettle

$\mathrm{a}, \mathrm{b}, \mathrm{c}-$ mean values denoted by different letters differ statistically significantly $(p<0.05)$

ABTS assays, also green tea extract demonstrated the highest antioxidant capacity while nettle extract exhibited the lowest antioxidant activity. Green tea contains phenolic compounds with antioxidant properties. The most effective antioxidant compounds are catechins that show the ability to scavenge-free radicals and to chelate metal ions. In addition, green tea extracts contain compounds such as terpenes, sesquiterpenes and organic acids. Catechin molecules are characterized by presence of various hydroxyl groups on A- and B-rings and hydroxyl group on carbon 3 of dihydropyran heterocycle (the C-ring). Their number and position in the molecule are the factors determining the antioxidant activity of flavonoids [23]. However, blackcurrant seed extracts contain rutin, isoquercetin and taxifolin. Compounds belonging to two major groups were detected in nettle extracts: phenolic acids and flavonoids. The presence of phenolic compounds, especially flavonoids and caffeic acid derivatives, in the nettle extract may also pronounce on its antioxidant effect although it is significantly less than plants from the Lamiaceae family [24]. The nettle extract had the lowest total phenolic content $\left(23.74 \mathrm{mg} \mathrm{GA} \mathrm{g}^{-1}\right.$ of the extract) and presented the lowest value of antioxidant activity in all the assays.

\section{Quality of fat from cookies after baking and during storage}

Baking caused the formation of primary and secondary lipid oxidation products, irrespective of variant (Fig. 1a, b). PVs of fat from cookies after baking were varied and ranged from 0.84 (variant with $1 \%$ GT extract) to
$1.22 \mathrm{mEqO} \mathrm{kg}{ }^{-1}$ fat (variant with $0.5 \%$ nettle extract). AV in cookie fat ranged from 1.64 for the sample with $1 \%$ GT to 2.79 for cookie fat with $0.5 \%$ extract of $\mathrm{N}$. The content of conjugated polyunsaturated FA such as hydroxy peroxides - dienes (K232) — in fat extracted from cookies after baking was the highest in the control sample (2.98) and sample with $0.5 \%$ addition of $\mathrm{N}$ (2.49), while the lowest (2.23) was in the sample of fat from the variant with $1.5 \%$ BC extract (Fig. 1c). The K268 indicator values were small, unrelated to the variant and did not exceed 0.75 (Fig. 1d).

Changes in oxidation products (PV, LA, K232, K268) were found in the fat of stored cookies. The first 2 months of the test showed constant growth in the amount of primary oxidation products in all variants. PVs ranged from 0.88 (variant with $1 \%$ GT) to $1.68 \mathrm{mEqO} \mathrm{kg}^{-1}$ fat (variant with $0.5 \% \mathrm{~N}$ ) and $1.70 \mathrm{mEqO} \mathrm{kg}{ }^{-1}$ (control variant). After 3 months of storage, the PV (in relation to PV after 2 months) was reduced in cookies with GT, BC extracts in samples with $1.5 \%$ extract of $\mathrm{N}$. After the whole test, the smallest PV characterized the fat from cookies with $1 \%$ addition of GT extract $\left(0.87 \mathrm{mEqO} \mathrm{kg}{ }^{-1}\right)$ and the highest with $0.5 \% \mathrm{~N}$ extract $\left(1.77 \mathrm{mEqO} \mathrm{kg}^{-1}\right)$-Fig. $1 \mathrm{a}$.

Increasing time of storage was associated with constant growth of secondary lipid oxidation products measured by AV (Fig. 1b), irrespective of variant. Fat from 1\% GT cookies was characterized by the lowest content of secondary oxidation products. (The AV after 3 months was 5.0.) On the other hand, the fastest increase in AV was observed for nettle extract samples. (After 3 months, the $\mathrm{AV}$ for fat from cookies with $0.5 \% \mathrm{~N}$ was 10.9 and for control sample 11.01.) 
Changes in the K232 and K268 ratios, as determined by the fats stored in the cookies, were small. Fat extracted from stored GT cookies was characterized by the lowest content of both dienes and trienes (after 3 months, respectively, 2.35 and 0.37 ). During storage, the content of dienes decreased, regardless of variant. Such a change was not observed for K268 (Fig. 1d).

The onset temperature $\left(t_{\mathrm{ON}}\right)$ is usually taken as a suitable parameter for characterizing lipid oxidation under non-isothermal condition. The sample with a higher $t_{\mathrm{ON}}$ is more stable than the one for which $t_{\mathrm{ON}}$ values obtained at the same heating rates are lower. The DSC curves of fat samples extracted from cookies without the addition of plant extracts and fortified with green tea, nettle and black currant seed extracts at a concentration of $1 \%$, analyzed at a heating rate of $10{ }^{\circ} \mathrm{C} \mathrm{min}{ }^{-1}$, are illustrated in Fig. 2. Their shapes are similar, but they are shifted toward higher temperatures depending on types of plant extracts added. The results listed in Table 2 show that the increase in the heating rate from 4 to $15^{\circ} \mathrm{C} \mathrm{min}{ }^{-1}$ led to an increase in $t_{\mathrm{ON}}$ values for all the tested fat samples, although they were lower than their counterparts with extracts for the control fat sample tested after baking without addition of plant extracts. However, (raw) fat used to prepare cookies is characterized by a higher onset oxidation temperature than fat extracted from cookies after baking. Application of high temperature during baking may influence stability of fat obtained from cookies. It was also found that stability of samples tested after baking and containing the plant extracts was significantly improved in comparison with the sample without plant material. Addition of $1 \%$ of green tea extract demonstrated the highest $t_{\mathrm{ON}}$ values. The oxidation onset temperature also increased for fat samples with the addition of nettle and black currant seed extracts in comparison with the control sample. In the case of fat samples with the addition of nettle extract, the highest onset oxidation temperatures were observed when nettle extract at a concentration of $1 \%$ was used. A similar observation was made for the samples enriched with black currant seed extracts. The oxidation onset temperature also increased for the fat samples with the addition of plant extracts after 3 months of their storage at room temperature compared to the sample without the addition of plant extracts. The fat extracted from cookies containing green tea extract was characterized by a higher onset oxidation temperature at each heating rates than their counterparts with nettle and black currant seed extracts. It was also noticed that the oxidation onset temperatures of samples with the addition of nettle extract after 3 months of storage were slightly higher than the samples after baking. However, the fat samples containing blackcurrant seed extracts at the concentrations of $0.5,1.0$ and $1.5 \%$, respectively, exhibit negligibly lower onset temperatures than their counterparts after storage at room temperature.

The kinetic parameters, namely activation energy, preexponential factor and induction time at 180 and $190{ }^{\circ} \mathrm{C}$, which were computed from $t_{\mathrm{ON}}$ for each sample tested are shown in Table 3. For fat samples tested after baking, the activation energy $\left(E_{\mathrm{a}}\right)$ values varied from 98.89 to $152.42 \mathrm{~kJ} \mathrm{~mol}^{-1}$ but after 3 months of storage they ranged from 85.79 to $140.96 \mathrm{~kJ} \mathrm{~mol}^{-1}$. The highest activation energy values were observed for the samples containing blackcurrant seed extracts among the tested fat samples. The calculated activation energy values for the tested samples depended on the type of used plant extracts and their concentration. In the case of nettle extracts, the $E_{\mathrm{a}}$ value after baking was the highest at the concentration of $1.5 \%$ and after storage at the level of $0.5 \%$. For samples containing blackcurrant seed extracts, this parameter was the highest at the level of $1.0 \%$ after baking and $0.5 \%$ after storage at room temperature. Based on the induction time calculated at $180{ }^{\circ} \mathrm{C}$, we can see that the average thermooxidative stability of samples studied after baking and storage for 3 months was the highest for the fat fraction with green tea extracts. Taking into account this parameter, the rank of tested fat samples with the addition of plant extracts resistant to thermo-oxidative decomposition after 3 months of storage increased in the following sequence: $\mathrm{N}$ $0.5 \%<\mathrm{N} 1.0 \%<\mathrm{N} 1.5 \%<\mathrm{BC} 1.5 \%<\mathrm{BC} 1.0 \%<\mathrm{BC}$ $0.5 \%<\mathrm{GT} 1 \%$.

\section{Effect of addition of plant extracts on cookies color and sensory properties}

The type of applied additive significantly influenced the color parameters (Table 4). The $L$ value decreases as the content of extracts increases. The highest percentage of red was shown in cookies with GT extract $(+5.13)$ and $1.5 \%$ BC extract $(+4.94)$, while the smallest value characterized the sample with the lowest addition of $\mathrm{N}$ extract $(+3.55)$. With the increase in the dose of $\mathrm{BC}$ extract, the proportion of yellow color decreased. The smallest value of the $b$ parameter was found in the sample with the highest addition of BC extract $(+19.82)$.

A statistically significant influence of applied extracts on the sensory distinctions rating was found (Table 5). Most of the products obtained high marks for color (above 7.0) they were golden brown. The addition of $\mathrm{N}$ extract resulted in lightening of cookie color (variant with $1.5 \mathrm{~N}$ rated lowest-6.8) and in the appearance of cracks on the surface. In turn, the addition of BC extract caused darkening and reduced the number of cracks on the surface of cookies.

GT extract caused the smell and taste of tea, and in addition the aroma of herbs in the cookies was the least 
(a)

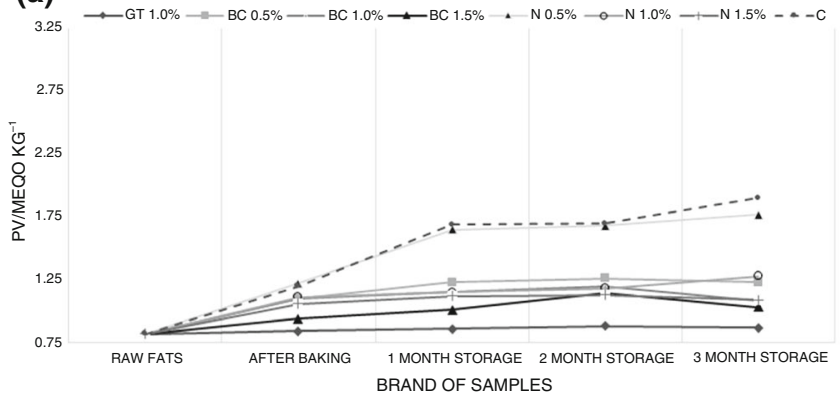

(c)
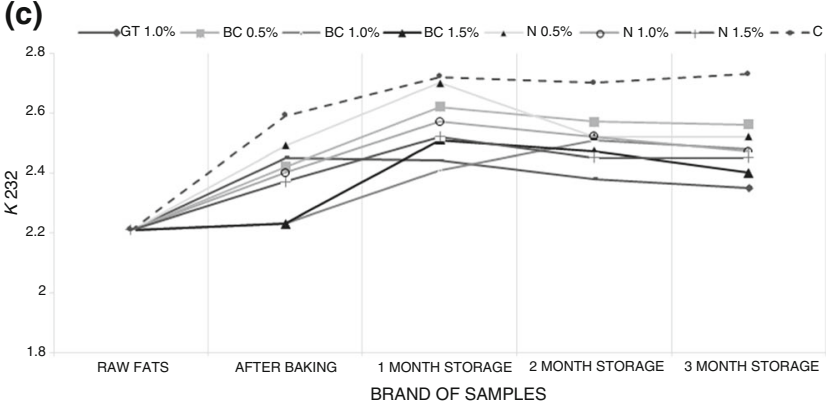

(b)

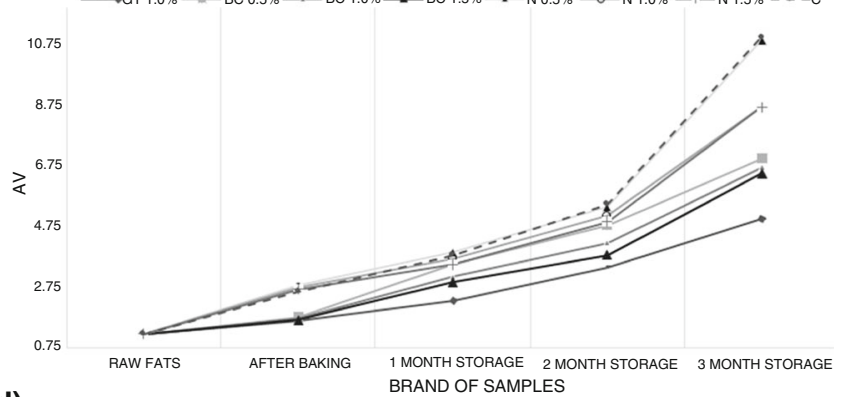

(d)

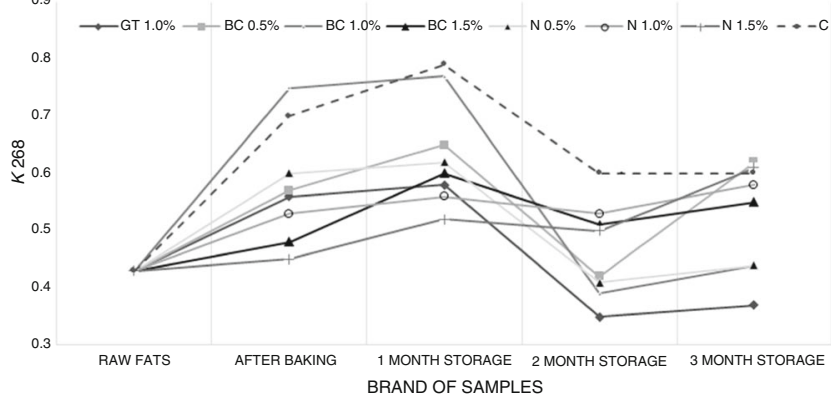

Fig. 1 Changes in the fat quality (a PV, b AV, c K232, d K268)

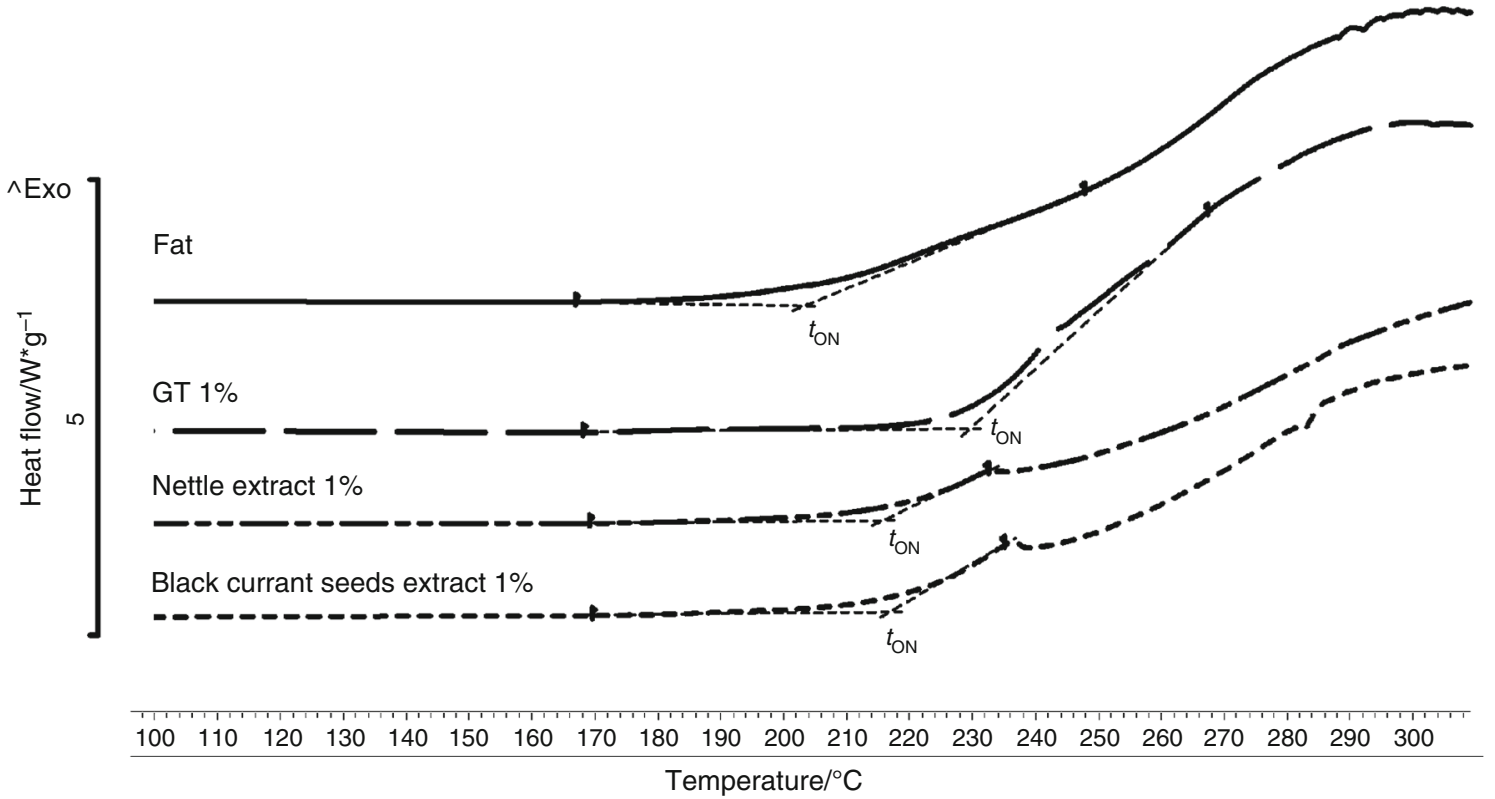

Fig. 2 Example of DSC scan of non-isothermal oxidation of fat samples extracted from cookies after baking containing plant extracts (GT, Nettle extract, Black currant seeds extract) and without them at heating rate $\beta=10{ }^{\circ} \mathrm{C} \mathrm{min}{ }^{-1}$

noticeable. The addition of blackcurrant extract resulted in an intensification of odor and fruit flavor. Nettle extracts, in turn, significantly increased the perception of the aroma and taste of herbs in cookies. According to evaluators, cookies with the most desirable smell were characterized by the largest addition of $\mathrm{BC}$ extract, while the cookies with $0.5 \%$ nettle extract had the least desirable odor. In addition, the sweet taste was the most noticeable in cookies with a nettle extract but the lowest sweetness was found in products with BC and GT extract. The type and amount of additives had the smallest effect on the texture of oat flake cookies.

General quality of the products was in the range from 6.4 (variant with $0.5 \% \mathrm{~N}$ ) to 7.6 (variant with GT and control sample). Cookies with green tea extract were the 
Table 2 Values of $t_{\text {on }}$ obtained for five heating rates of samples in the oxidation processes of fat extracted from cookies depending on the type and concentration of plant extracts

\begin{tabular}{|c|c|c|c|c|c|c|c|c|c|}
\hline \multirow{3}{*}{$\begin{array}{l}\text { Heating rate } \beta / \\
{ }^{\circ} \mathrm{C} \min ^{-1}\end{array}$} & \multicolumn{9}{|c|}{ Fat from control cookies and from cookies with $1 \%$ GT } \\
\hline & \multirow[t]{2}{*}{ Raw fat } & \multicolumn{4}{|l|}{ After baking } & \multicolumn{4}{|c|}{ After 3 months of storage } \\
\hline & & \multicolumn{2}{|l|}{$\mathrm{C}$} & \multicolumn{2}{|l|}{$1 \% \mathrm{GT}$} & \multicolumn{2}{|l|}{$\mathrm{C}$} & \multicolumn{2}{|c|}{$1 \% \mathrm{GT}$} \\
\hline 4 & $194.89^{\mathrm{ab}} \pm 0.61$ & \multicolumn{2}{|c|}{$190.69^{\mathrm{a}} \pm 0.71$} & \multicolumn{2}{|c|}{$214.50^{1} \pm 0.89$} & \multicolumn{2}{|c|}{$187.13^{\mathrm{a}} \pm 0.57$} & \multicolumn{2}{|c|}{$217.35^{\mathrm{m}} \pm 0.79$} \\
\hline 7.5 & $202.92^{\mathrm{a}} \pm 0.78$ & \multicolumn{2}{|c|}{$198.42^{\mathrm{a}} \pm 0.81$} & \multicolumn{2}{|c|}{$223.39^{1} \pm 0.96$} & \multicolumn{2}{|c|}{$194.87^{\mathrm{a}} \pm 0.77$} & \multicolumn{2}{|c|}{$229.03^{\mathrm{m}} \pm 1.09$} \\
\hline 10 & $206.73^{\mathrm{ab}} \pm 0.98$ & \multicolumn{2}{|c|}{$203.11^{\mathrm{a}} \pm 0.93$} & \multicolumn{2}{|c|}{$229.19^{\mathrm{m}} \pm 1.17$} & \multicolumn{2}{|c|}{$199.65^{\mathrm{a}} \pm 0.91$} & \multicolumn{2}{|c|}{$235.34^{\mathrm{n}} \pm 1.15$} \\
\hline 12.5 & $209.92^{\mathrm{a}} \pm 1.03$ & \multicolumn{2}{|c|}{$207.61^{\mathrm{a}} \pm 1.23$} & \multicolumn{2}{|c|}{$232.31^{\mathrm{n}} \pm 1.26$} & \multicolumn{2}{|c|}{$203.61^{\mathrm{a}} \pm 1.04$} & \multicolumn{2}{|c|}{$238.05^{\circ} \pm 1.19$} \\
\hline 15 & $214.01^{\mathrm{ab}} \pm 1.26$ & \multicolumn{2}{|c|}{$210.47^{\mathrm{a}} \pm 1.54$} & \multicolumn{2}{|c|}{$237.41^{\mathrm{n}} \pm 1.39$} & $207.17^{\mathrm{a}}$ & \pm 1.27 & 243. & $6^{\circ} \pm 1.42$ \\
\hline Heating rate $\beta /{ }^{\circ} \mathrm{C} \min ^{-1}$ & Fat from cookies & with nettle extract & & & & & & & \\
\hline & After baking & & & & After 3 & months o & storage & & \\
\hline & $0.5 \% \mathrm{~N}$ & $1.0 \% \mathrm{~N}$ & $1.5^{c}$ & & $0.5 \% \mathrm{~N}$ & & $1 \% \mathrm{~N}$ & & $1.5 \% \mathrm{~N}$ \\
\hline 4 & $196.01^{b} \pm 0.68$ & $197.10^{\mathrm{c}} \pm 0.59$ & 196 & $98^{\mathrm{c}} \pm 0.69$ & $197.66^{\mathrm{d}}$ & \pm 0.75 & $198.91^{\mathrm{e}} \pm$ & 0.73 & $199.86^{\mathrm{gh}} \pm 0.65$ \\
\hline 7.5 & $207.39^{\mathrm{b}} \pm 0,73$ & $209.07^{\mathrm{e}} \pm 0.71$ & 208 & $09^{\mathrm{d}} \pm 0.71$ & $209.82^{\mathrm{g}}$ & \pm 0.99 & $209.45^{\mathrm{f}} \pm$ & 0.86 & $209.85^{\mathrm{g}} \pm 0.79$ \\
\hline 10 & $212.39^{\mathrm{c}} \pm 0.84$ & $215.14^{\mathrm{g}} \pm 0.82$ & 213 & $12^{\mathrm{e}} \pm 0.79$ & $212.73^{\mathrm{d}}$ & \pm 1.06 & $216.61^{\mathrm{i}} \pm$ & 1.08 & $220.05^{1} \pm 0.98$ \\
\hline 12.5 & $215.99^{c} \pm 1.03$ & $217.10^{\mathrm{f}} \pm 1.13$ & 216 & $80^{\mathrm{e}} \pm 0.83$ & $217.74^{\mathrm{g}}$ & \pm 1.12 & $224.08^{\mathrm{m}} \pm$ & 1.18 & $221.21^{\mathrm{j}} \pm 1.14$ \\
\hline 15 & $220.57^{\mathrm{d}} \pm 1.19$ & $222.01^{\mathrm{g}} \pm 1.21$ & 221 & $34^{\mathrm{f}} \pm 0.99$ & $223.20^{\mathrm{i}}$ & \pm 1.17 & $227.50^{1} \pm$ & 1.28 & $226.95^{\mathrm{k}} \pm 1.16$ \\
\hline Heating rate $\beta /{ }^{\circ} \mathrm{C} \min ^{-1}$ & Fat from cookies & with black currant & seeds & extract & & & & & \\
\hline & After baking & & & & After 3 & months $\mathrm{C}$ & f storage & & \\
\hline & $0.5 \% \mathrm{BC}$ & $1.0 \% \mathrm{BC}$ & 1.5 & $6 \mathrm{BC}$ & $0.5 \% \mathrm{~B}$ & & $1.0 \% \mathrm{BC}$ & & $1.5 \% \mathrm{BC}$ \\
\hline 4 & $202.03^{\mathrm{i}} \pm 0.59$ & $202.95^{\mathrm{j}} \pm 0.65$ & 20 & $58^{\mathrm{k}} \pm 0.61$ & $200.06^{\mathrm{h}}$ & \pm 0.72 & $199.60^{\mathrm{f}} \pm$ & 0.46 & $202.17^{\mathrm{i}} \pm 0.66$ \\
\hline 7.5 & $212.18^{\mathrm{i}} \pm 0.89$ & $211.07^{\mathrm{h}} \pm 0.86$ & & $31^{\mathrm{j}} \pm 0.84$ & $207.80^{\mathrm{c}}$ & \pm 0.79 & $209.44^{\mathrm{f}} \pm$ & 0.87 & $213.13^{\mathrm{k}} \pm 0.87$ \\
\hline 10 & $215.43^{\mathrm{h}} \pm 0.96$ & $214.33^{\mathrm{f}} \pm 0.89$ & 218 & $34^{\mathrm{k}} \pm 0.98$ & $211.25^{\mathrm{b}}$ & \pm 0.93 & $215.11^{\mathrm{g}} \pm$ & 0.93 & $217.92^{\mathrm{j}} \pm 0.93$ \\
\hline 12.5 & $218.92^{\mathrm{i}} \pm 1.09$ & $216.21^{\mathrm{d}} \pm 0.92$ & 222 & $59^{\mathrm{k}} \pm 1.12$ & $215.03^{\mathrm{b}}$ & \pm 1.05 & $218.10^{\mathrm{h}} \pm$ & 1.08 & $223.63^{1} \pm 1.27$ \\
\hline 15 & $222.99^{\mathrm{h}} \pm 1.27$ & $219.37^{\mathrm{c}} \pm 1.03$ & & $44^{\mathrm{j}} \pm 1.26$ & $217.11^{\mathrm{b}}$ & \pm 1.17 & $220.82^{\mathrm{e}} \pm$ & 1.28 & $227.85^{\mathrm{m}} \pm 1.38$ \\
\hline
\end{tabular}

$C$ control, $G T$ green tea, $B C$ blackcurrant seed, $N$ nettle

$\mathrm{a}, \mathrm{b}, \mathrm{c}-$ mean values denoted by different letters (in lines) differ statistically significantly $(p<0.05)$

most desirable, while the least desirable were those that were enriched with $0.5 \%$ nettle extract.

\section{Discussion}

Pastry products are very popular because they are tasty and easy to eat. Such products could be a great carrier of substances increasing their nutritional value. A product with addition of $33 \%$ oat flakes was created. It can be considered as functional food for which a nutrition claim can be made, because a portion would provide at least $3 \mathrm{~g}$ of dietary fiber (DF) [14]. The appropriate level of DF in the diet is very important, because it plays a major role in prevention of civilization diseases $[3,6]$. At the same time, a large amount of oat flakes (fat content of 9.5\%) was added to the analyzed products as labile fat (Table 1), which can easily degrade at high temperatures and during storage of biscuits. Zbikowska and Rutkowska [8] observed that as the amount of oat flakes increased (10, 20 and 30\% in relation to flour), the rate of fat degradation in cookies also increased. The authors stated that especially $30 \%$ oatmeal additive reduces durability of cookies. The dominant FA in oat flakes was polyunsaturated FA $(76.8 \%$ Table 1), which easily undergoes degradation processes.

The green tea extract used in the study was characterized by the highest antioxidant activity (Table 1). The differences between the results obtained in the work and the literature data may be due to the differences in materials which were analyzed.

High temperature during baking had a negative influence on fat quality [20]. The plant extracts affected the rate of oxidation changes during baking. The least effective in inhibiting fat oxidation in cookies was the $0.5 \% \mathrm{~N}$ extract. 
Table 3 Kinetic parameters characterizing the thermooxidizing degradation of fat from cookies depending on the type and concentration of plant extracts

\begin{tabular}{|c|c|c|c|c|c|}
\hline \multirow[t]{3}{*}{ Parameter } & \multicolumn{5}{|c|}{ Fat from control cookies and from cookies with $1.0 \%$ GT } \\
\hline & \multirow[t]{2}{*}{ Raw fat } & \multicolumn{2}{|c|}{ After baking } & \multicolumn{2}{|c|}{ After 3 months of storage } \\
\hline & & $\mathrm{C}$ & $1.0 \% \mathrm{GT}$ & $\mathrm{C}$ & $1.0 \% \mathrm{GT}$ \\
\hline$-a$ & 6.995 & 6.409 & 6.316 & 6.316 & 5.724 \\
\hline$b$ & 15.562 & 14.440 & 13.572 & 14.345 & 12.273 \\
\hline$R^{2}$ & 0.993 & 0.992 & 0.991 & 0.992 & 0.996 \\
\hline$E_{\mathrm{a}} / \mathrm{kJ} \mathrm{mol}^{-1}$ & 127.37 & 116.69 & 115.00 & 114.99 & 104.23 \\
\hline $\log Z$ & 13.69 & 12.60 & 11.74 & 12.52 & 10.49 \\
\hline$\tau / \min$ at $180{ }^{\circ} \mathrm{C}$ & 9.80 & 7.09 & 32.79 & 5.43 & 33.44 \\
\hline$\tau / \min$ at $190^{\circ} \mathrm{C}$ & 4.71 & 3.64 & 16.98 & 2.81 & 18.42 \\
\hline
\end{tabular}

Parameters $\quad$ Fat from cookies with nettle extract

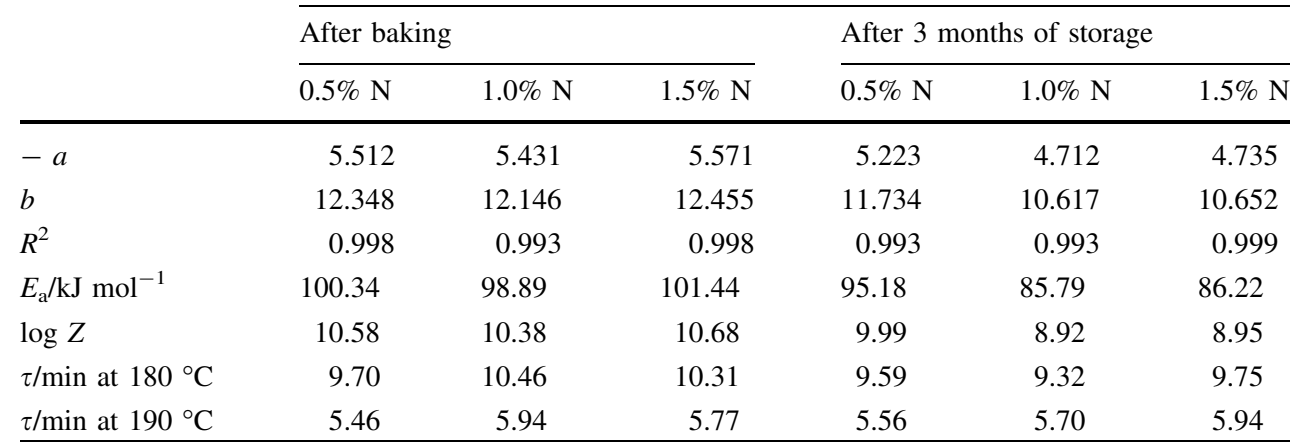

Parameters $\quad$ Fat from cookies with black currant seeds extract

\begin{tabular}{|c|c|c|c|c|c|c|}
\hline & \multicolumn{3}{|c|}{ After baking } & \multicolumn{3}{|c|}{ After 3 months of storage } \\
\hline & $0.5 \% \mathrm{BC}$ & $1.0 \% \mathrm{BC}$ & $1.5 \% \mathrm{BC}$ & $0.5 \% \mathrm{BC}$ & $1 \% \mathrm{BC}$ & $1.5 \% \mathrm{BC}$ \\
\hline$-a$ & 6.628 & 8.371 & 5.922 & 7.792 & 6.222 & 5.349 \\
\hline$b$ & 14.55 & 18.18 & 13.044 & 16.968 & 13.761 & 11.868 \\
\hline$R^{2}$ & 0.995 & 0.995 & 0.993 & 0.998 & 0.998 & 0.995 \\
\hline$E_{\mathrm{a}} / \mathrm{kJ} \mathrm{mol}^{-1}$ & 120.68 & 152.42 & 107.83 & 140.96 & 113.28 & 97.39 \\
\hline $\log Z$ & 12.70 & 16.23 & 11.20 & 15.05 & 11.94 & 10.11 \\
\hline$\tau / \min$ at $180{ }^{\circ} \mathrm{C}$ & 16.26 & 21.88 & 16.98 & 15.82 & 13.14 & 13.07 \\
\hline$\tau / \min$ at $190{ }^{\circ} \mathrm{C}$ & 8.14 & 9.13 & 9.15 & 7.05 & 6.85 & 7.48 \\
\hline
\end{tabular}

What is more, a very good protective effect was shown by the GT extract, which confirmed other researchers' opinion that green tea extracts can be a good source of antioxidants added to food [10].

The extended storage time of cookies negatively affects the quality of fat contained [20]. Oxidation processes are of particular significance in cookies as they contain high counts of fat. In our study, we observed a downgrade in PV after 3 months at the end of cookie storage (variant with additions of GT extracts, $1 \% \mathrm{BC}$ and $1.5 \% \mathrm{~N}$ ) compared to PV after 2 months of storage. This was due to decomposition of hydroperoxides leading to compounds such as alcohols, aldehydes and ketones, i.e., to autoxidative rancidity [22]. As explained by Aidos et al. [25], the peroxide increases with time to a maximum level and then decomposes rapidly to secondary products resulting in decreased PV. This phenomenon was confirmed by high AVs in cookies stored for 3 months (Fig. 1a, b). The content of polyunsaturated fatty acids (PUFA) in cookies, increasing with the addition of oat flakes (33\%), which contain as much as $9.5 \%$ of lipids, mainly PUFA (44\%), specifically linoleic acid $(42.7 \%)$, induced intense generation of oxidation products as shown by PVs after 3-month storage.

As in the case of baking, the most effective antioxidant activity was shown in the GT extract. Similarly, MildnerSzkudlarz et al. [10] observed high antioxidant activity of fresh green tea extract, obtained just before the study. The authors found a significant increase in oxidative stability of fat thermostated $\left(60^{\circ} \mathrm{C}\right.$, for 20 days) in biscuit packs. 
Table 4 Values of color parameters of cookies with oat flakes depending on the type and concentration of plant extracts

\begin{tabular}{llll}
\hline Variant & \multicolumn{3}{l}{ Color parameters } \\
\cline { 2 - 4 } & $L$ & $a$ & $b$ \\
\hline $\mathrm{C}$ & $68.30^{\mathrm{e}}$ & $+5.46^{\mathrm{e}}$ & $+20.45^{\mathrm{b}}$ \\
$1.0 \% \mathrm{GT}$ & $65.44^{\mathrm{ab}}$ & $+5.13^{\mathrm{e}}$ & $+20.31^{\mathrm{ab}}$ \\
$0.5 \% \mathrm{BC}$ & $67.33^{\mathrm{de}}$ & $+4.60^{\mathrm{cd}}$ & $+21.67^{\mathrm{c}}$ \\
$1.0 \% \mathrm{BC}$ & $66.90^{\mathrm{cd}}$ & $+4.29^{\mathrm{bc}}$ & $+20.30^{\mathrm{ab}}$ \\
$1.5 \% \mathrm{BC}$ & $64.85^{\mathrm{a}}$ & $+4.94^{\mathrm{de}}$ & $+19.82^{\mathrm{a}}$ \\
$0.5 \% \mathrm{~N}$ & $68.19^{\mathrm{e}}$ & $+3.55^{\mathrm{a}}$ & $+20.73^{\mathrm{b}}$ \\
$1.0 \% \mathrm{~N}$ & $68.04^{\mathrm{e}}$ & $+3.99^{\mathrm{b}}$ & $+21.60^{\mathrm{c}}$ \\
$1.5 \% \mathrm{~N}$ & $66.08^{\mathrm{bc}}$ & $+3.97^{\mathrm{ab}}$ & $+20.33^{\mathrm{ab}}$ \\
\hline
\end{tabular}

$C$ control, $N$ nettle extract, $B C$ black currant seeds extract, $G T$ green tea extract

a, b, c-mean values denoted by different letters (in column) differ statistically significantly $(p<0.05)$

During oxidation, under the influence of time, temperature and air, linolenic and linoleic acids are oxidized in hydroxy peroxides in which double bonds are conjugateddienes [26]. This work shows the changes in the $K 232$ and $K 268$ values. As reported by Del Caro et al. [27], the $K 268$ value of fat during storage is influenced by light access. In our study, the cookies were stored without light, so the changes in the contents of the trienes were small. During storage, the content of dienes in the final phase of the test decreased. A similar trend was observed in studies by Caponio et al. [28].

The green tea extract used in our study was characterized by higher polyphenol content and antioxidant activity than the extracts obtained from blackcurrant seeds and nettle leaves. Total polyphenol content in green tea samples measured by Chrpova et al. [29] varied between 63.7 and $112.8 \mathrm{mg}$ equivalent of gallic acid per gram of dried leaves. In turn, in the study by Stankovic et al. [30], the values for total phenolic content of green extracts ranged from 16.02 to $233.68 \mathrm{mg} \mathrm{GA} \mathrm{g}^{-1}$ and were dependent on the solvent used for the extraction. Also, the origin and type of tea affect the polyphenol content in extracts. The polyphenols in green tea belong to various classes of compounds including: catechins, flavones, their glucosides and phenolic acids. The presence of catechins in green tea, which may act as radical scavengers, might also influence the antioxidant activity of extracts prepared from tea. The results of our study on polyphenol contents in blackcurrant seeds are slightly higher than data reported by Kahkonen et al. [31]. However, the total phenolic content in nettle extract and its antioxidant activity were lower than the values obtained in studies by Ghaima et al. [32].

In conclusion, the applied plant extracts, especially green tea extract, can be used to retard lipid oxidation and to extend the shelf life of food products. Jaswir et al. [33] using DSC analysis showed that addition of the plant extracts to the oil reduces the oxidation as evidenced by longer $t_{\mathrm{ON}}$ of antioxidant-treated samples. Also Shu-Yao et al. [34] revealed that extract of Pleurotus citrinopileatus combined with vitamin $\mathrm{E}$ was effective as natural antioxidant in camelia oil. Similarly, Kozlowska et al. [35] observed that oxidative stability of the lipid fraction extracted from cookies after baking was improved when spice extracts were used as antioxidants. Turan [37] also reported that addition of plant extracts increased the induction period of canola oil. The autoxidation of fats is a complicated, multistep and exothermic process that may be studied using DSC technique. DSC analysis can be adopted as a method with several advantages, such as a shorter analysis time, small amounts of study samples required and the possibility of continuous monitoring of the total thermal effect of lipid oxidation [38]. It is also a good thermal method for determining kinetic parameters of non-inhibited and inhibited fats and oils oxidation. The first exothermal process observed on DSC curves of non-isothermal oxidation of fat is autoxidation, in which hydroperoxides are formed and the starting temperature of that process can be used to calculate activation energy, pre-exponential factor and oxidation rate constant [39]. Higher $t_{\mathrm{ON}}$ values are linked to better oxidative stability or longer shelf life of studied fats and are useful to evaluate antioxidant activity of natural or synthetic antioxidants added to samples. Therefore, in our study fat extracted from cookies containing green tea extract was found to be more stable in terms of oxidation than fat obtained from cookies enriched with other plant extracts and fat without the addition of natural antioxidant. After 3-month storage of cookies, the greatest changes in $t_{\mathrm{ON}}$ values were observed for the sample without plant extracts, whereas the samples supplemented with green tea and nettle extracts were more stable. Application of high temperature during the baking process promotes formation of Maillard reaction products responsible for color and taste of food products [40]. In turn, during storage of food samples rich in fat, their fatty acid composition, presence of antioxidative and prooxidative concomitant compounds, and interactions between them are important [41].

Consumers pay special attention to the sensory characteristics of fragile cookies, on which the quality of the fat has a significant effect. According to other scientific work $[35,36]$, the possible positive effect of addition of plant extracts is not only on nutritional value but also on the taste. According to the authors, natural antioxidants found in herbs and fruits increase the polygenic FA stability and also may contribute to unique sensory properties as they contain compounds with a specific taste and odor. Similarly, in our research applied plant extracts influenced the 
Table 5 Sensory properties of oat flake cookies depending on the type and concentration of plant extracts

\begin{tabular}{lllllllll}
\hline Quality characteristics & $\mathrm{C}$ & $\mathrm{GT}$ & $\mathrm{BC} 0.5 \%$ & $\mathrm{BC} 1.0 \%$ & $\mathrm{BC} 1.5 \%$ & $\mathrm{~N} 0.5 \%$ & $\mathrm{~N} 1.0 \%$ & $\mathrm{~N} 1.5 \%$ \\
\hline Appearance & & & & & & & & \\
Color & $7.4^{\mathrm{cd}}$ & $7.0^{\mathrm{b}}$ & $7.3^{\mathrm{c}}$ & $7.9^{\mathrm{e}}$ & $7.2^{\mathrm{c}}$ & $7.0^{\mathrm{b}}$ & $6.8^{\mathrm{a}}$ & $7.5^{\mathrm{d}}$ \\
Cracks on the surface & $4.9^{\mathrm{b}}$ & $4.8^{\mathrm{b}}$ & $4.8^{\mathrm{b}}$ & $4.5^{\mathrm{a}}$ & $5.0^{\mathrm{c}}$ & $5.5^{\mathrm{d}}$ & $6.6^{\mathrm{e}}$ & $4.7^{\mathrm{b}}$ \\
Smell & & & & & & & & \\
Herbal & $2.1^{\mathrm{a}}$ & $2.0^{\mathrm{a}}$ & $3.0^{\mathrm{b}}$ & $3.1^{\mathrm{bc}}$ & $3.2^{\mathrm{c}}$ & $3.5^{\mathrm{d}}$ & $3.7^{\mathrm{e}}$ & $3.1^{\mathrm{bc}}$ \\
Tea intense & $0.9^{\mathrm{a}}$ & $4.4^{\mathrm{f}}$ & $3.5^{\mathrm{e}}$ & $3.1^{\mathrm{c}}$ & $2.1^{\mathrm{b}}$ & $1.8^{\mathrm{a}}$ & $1.7^{\mathrm{a}}$ & $3.3^{\mathrm{d}}$ \\
Fruit & $1.0^{\mathrm{a}}$ & $3.3^{\mathrm{c}}$ & $4.0^{\mathrm{d}}$ & $4.8^{\mathrm{f}}$ & $1.8^{\mathrm{a}}$ & $2.0^{\mathrm{ab}}$ & $2.2^{\mathrm{b}}$ & $4.5^{\mathrm{e}}$ \\
Desirable & $6.7^{\mathrm{b}}$ & $6.8^{\mathrm{b}}$ & $6.8^{\mathrm{b}}$ & $6.8^{\mathrm{b}}$ & $7.8^{\mathrm{c}}$ & $5.6^{\mathrm{a}}$ & $5.8^{\mathrm{a}}$ & $7.0^{\mathrm{b}}$ \\
Texture & & & & & & & & \\
Hardness & $7.7^{\mathrm{b}}$ & $8.1^{\mathrm{d}}$ & $7.7^{\mathrm{b}}$ & $7.7^{\mathrm{b}}$ & $7.9^{\mathrm{cd}}$ & $7.8^{\mathrm{bc}}$ & $7.9^{\mathrm{cd}}$ & $7.6^{\mathrm{ab}}$ \\
Fragility & $7.5^{\mathrm{c}}$ & $7.3^{\mathrm{b}}$ & $7.6^{\mathrm{c}}$ & $7.5^{\mathrm{c}}$ & $7.6^{\mathrm{c}}$ & $6.9^{\mathrm{a}}$ & $7.8^{\mathrm{d}}$ & $7.3^{\mathrm{b}}$ \\
Taste & & & & & & & & \\
Sweet & $7.2^{\mathrm{c}}$ & $6.0^{\mathrm{a}}$ & $5.6^{\mathrm{a}}$ & $8.4^{\mathrm{d}}$ & $7.6^{\mathrm{c}}$ & $8.4^{\mathrm{d}}$ & $8.7^{\mathrm{e}}$ & $6.8^{\mathrm{b}}$ \\
Herbal & $1.0^{\mathrm{a}}$ & $2.5^{\mathrm{b}}$ & $1.6^{\mathrm{a}}$ & $1.7^{\mathrm{a}}$ & $2.3^{\mathrm{b}}$ & $2.5^{\mathrm{b}}$ & $2.7^{\mathrm{c}}$ & $1.7^{\mathrm{a}}$ \\
Tea intense & $0.7^{\mathrm{a}}$ & $4.0^{\mathrm{e}}$ & $2.5^{\mathrm{d}}$ & $2.1^{\mathrm{c}}$ & $1.0^{\mathrm{a}}$ & $1.1^{\mathrm{a}}$ & $1.9^{\mathrm{b}}$ & $2.0^{\mathrm{bc}}$ \\
Fruit & $0.9^{\mathrm{a}}$ & $1.9^{\mathrm{a}}$ & $2.5^{\mathrm{b}}$ & $3.2^{\mathrm{c}}$ & $1.8^{\mathrm{a}}$ & $1.9^{\mathrm{a}}$ & $1.8^{\mathrm{a}}$ & $3.0^{\mathrm{c}}$ \\
Desirable & $8.7^{\mathrm{f}}$ & $8.8^{\mathrm{f}}$ & $7.9^{\mathrm{c}}$ & $8.2^{\mathrm{d}}$ & $8.4^{\mathrm{de}}$ & $7.6^{\mathrm{b}}$ & $7.3^{\mathrm{a}}$ & $8.3^{\mathrm{d}}$ \\
Overall quality & $7.6^{\mathrm{d}}$ & $7.6^{\mathrm{d}}$ & $7.4^{\mathrm{c}}$ & $7.3^{\mathrm{c}}$ & $7.5^{\mathrm{d}}$ & $6.4^{\mathrm{a}}$ & $7.0^{\mathrm{d}}$ & $7.1^{\mathrm{b}}$ \\
\hline$C$ Control $N$ & & & & & &
\end{tabular}

$C$ control, $N$ nettle, $G T$ green tea, $B C$ blackcurrant seeds

$\mathrm{a}, \mathrm{b}, \mathrm{c}-$ mean values denoted by different letters (in column) differ statistically significantly $(p<0.05)$ sensory quality of oat flake cookies. Most evaluators considered the taste and smell of the products as desirable. They positively referred to the fruit and tea scent and taste of cookies.

\section{Conclusions}

The type and amount of addition of plant extracts influenced the rate of fat oxidation changes in oat flake cookies. The most effective protection was shown by the green tea extract and the weakest by the nettle extract (regardless of the amount of the additive).

The addition of plant extracts to oat flake cookies, regardless of the type or dose, influenced the sensory properties of oat flake cookies. The most desirable products were those with the green tea extract and the highest proportion of blackcurrant extract. Other products were evaluated as less desirable, but they were still of good quality and it could be expected that such products would be accepted by a large group of consumers. The results obtained from non-isothermal DSC showed that oxidative stability of fat extracted from cookies after baking was improved when green tea extract as antioxidant at a concentration of $1 \%$ was used. During storage of cookies for 3 months, it was observed that fat from cookies without plant extracts was characterized by lower $t_{\mathrm{ON}}$ values than samples with the addition of nettle and black currant seed extracts. The best antioxidant activity was also shown by the green tea extract. The green tea extract may be a suitable natural additive to protect fats from oxidation.

Acknowledgements The authors declare no conflict of interest. The research was carried out within the framework of the research task financed by funds of the Faculty of Food Science of Warsaw University of Life Sciences (WULS-SGGW).

Open Access This article is distributed under the terms of the Creative Commons Attribution 4.0 International License (http://creative commons.org/licenses/by/4.0/), which permits unrestricted use, distribution, and reproduction in any medium, provided you give appropriate credit to the original author(s) and the source, provide a link to the Creative Commons license, and indicate if changes were made.

\section{References}

1. Maćkowiak K, Torlińska-Walkowiak N, Torlińska B. Dietary fibre as an important constituent of the diet. Postepy Hig Med Dosw. 2016;70:104-9.

2. Zbikowska A, Rutkowska J, Kowalska M. Consumption safety of pastries, confectionery and potato products as related to fat content. J Am Coll Nutr. 2015;34(6):507-14.

3. Mackie A, Rigby N, Harvey P, Bajka B. Increasing dietary oat fiber decreases the permeability of intestinal mucus. J Funct Foods. 2016;26:418-27.

4. InterAct Consortium. Dietary fibre and incidence of type 2 diabetes in eight European countries: the EPIC-InterAct Study and a meta-analysis of prospective studies. Diabetologia. 2015;58(7):1394-408.

5. Liu Y, Colditz GA, Cotterchio M, Boucher BA, Kreiger N. Adolescent dietary fiber, vegetable fat, vegetable protein, and nut 
intakes and breast cancer risk. Breast Cancer Res Treat. 2014;145:461-70.

6. EFSA-NDA. Scientific opinion on the substantiation of a health claim related to barley beta-glucans and lowering of blood cholesterol and reduced risk of (coronary) heart disease pursuant to Article 14 of Regulation (EC) No 1924/2006. EFSA J/Eur Food Saf Auth. 2011;9(12):2471-84.

7. Zhou M, Robards K, Glennie-Holmes M, Helliwell S. Oat lipids. J Am Oil Chem Soc. 1999;76:159-69.

8. Zbikowska A, Rutkowska J. Quality of fats cookies as affected by storage and the addition of oat flakes. Cereal Chem. 2011;88(3):234-8.

9. Marquez-Ruiz G, Garcia-Martinez MC, Holgado F. Changes and effects of dietary oxidized lipids in the gastrointestinal tract. Lipids Insights. 2008;2:11-9.

10. Mildner-Szudlarz S, Zawirska-Wojtasiak R, Obuchowski W, Gośliński M. Evaluation of antioxidant activity of green tea extract and its effect on the biscuits lipid fraction oxidative stability. J Food Sci. 2009;8:362-70.

11. Lu TM, Lee Ch, Mau JL, Lin SD. Quality and antioxidant property of green tea sponge cake. Food Chem. 2010;119:1090-5.

12. Gulcin I, Kufrevioglu OI, Oktay M, Buyukokuroglu ME. Antioxidant, antimicrobial, antiulcer and analgesic activities of nattle (Urticia doicia L). J Ethnopharmacol. 2004;90:205-15.

13. Pachołek B, Małecka M. Black currant seeds as a source of natural antioxidants. Oilseed Crops. 2000;21:675-82.

14. Regulation (EC) No 1924/2006 of The European Parliament and of The Council of 20 December 2006 on nutrition and health claims made on foods.

15. Folch J, Lees M, Sloane-Stanley GH. A simple method for isolation and purification of total lipids from animal tissues. J Biol Chem. 1957;226:497-509.

16. Kozlowska M, Kowalska D, Gruczynska E, Kowalski B. Effect of ethanolic extracts from marjoram, thyme and oregano on thermooxidative degradation of rapeseed oil. Riv Ital Sostanze Gr. 2013;90:43-8.

17. Singleton VL, Rossi JA. Colorimetry of total phenolics with phosphomolybdic-phosphotungstic acid reagents. Am J Enol Viticult. 1965;16:144-58.

18. Gow-Chin Y, Hui-Yin C. Antioxidant activity of various tea extracts in relation to their antimutagenicity. J Agric Food Chem. 1995;43:27-32.

19. Re R, Pellegrini N, Proteggente A, Pannala A, Yang M, RiceEvans C. Antioxidant activity applying an improved ABTS radical cation decolorization assay. Free Radic Bio Med. 1999;26:1231-7.

20. Żbikowska A, Kowalska M, Rutkowska J, Kozłowska M, Onacik-Gür S. Impact of green tea extract addition on oxidative changes in the lipid fraction of pastry products. Acta Sci Pol Technol Aliment. 2017;16(1):25-32.

21. PN-A-86902. Animal and vegetable oil and fats-Bakery and confectionery fats. Warsaw, PKN. 1997.

22. Pomeranz Y. Biochemical, functional, and nutritive changes during storage. In: Sauer DB, editor. Storage of cereal grains and their products. MN: American Association of Cereal Chemists, St Paul; 1992.

23. Senanayake SPJN. Green tea extract: chemistry, antioxidant properties and food applications-a review. J Funct Foods. 2013;5:1529-41. https://doi.org/10.1016/j.jff.2013.08.011.

24. Kozłowska M, Ścibisz I, Zaręba D, Ziarno M. Antioxidant properties and effect on lactic acid bacterial growth of spice extracts. CyTA J Food. 2015;13:573-7.

25. Aidos I, Lourenco S, Van Der Padt A, Luten JB, Boom RM. Stability of crude herring oil produced from fresh byproducts: influence of temperature during storage. $\mathrm{J}$ Food Sci. 2002;67:3314-20.

26. Jerzewska M, Ptasznik S. Identification of olive oil available on the domestic market based on the fatty acid composition. Edible Fats. 2009;41(1/2):32-7.

27. Del Caro A, Vacca V, Poiana M, Fenu P, Piga A. influence of technology, storage and exposure on components of extra virgin olive oil (Bosana cv) from whole and de-stoned fruits. Food Chem. 2006;98:311-6.

28. Caponio F, Bilancia MT, Pasqualone A, Sikorska E, Gomes T. Influence of the exposure to light on extra virgin olive oil during storage. Eur Food Res Technol. 2005;221:92-8.

29. Chrpova D, Kourimska L, Gordon MH, Hermanova D, Roubickova D, Panek J. Antioxidant activity of selected phenols and herbs used in diets for medical conditions. Czech J Food Sci. 2010;28:317-25.

30. Stankovic MS, Niciforovic N, Topuzovic M, Solujic S. Total phenolic content, flavonoids concentrations and antioxidant activity of the whole plant and plant parts extracts from Teucrium montanum L., var montanum, $f$. supinum (L.). Reichenb Biotechnol EQ. 2011;25:2222-7.

31. Kahkonen MP, Hopia AI, Vuorela HJ, Rauha JP, Pihlaja K, Kujala TS, Heinonen M. Antioxidant activity of plant extracts containing phenolic compounds. J Agric Food Chem. 1999;47:3954-62.

32. Ghaima KK, Hashim NM, Ali SA. Antibacterial and antioxidant activities of ethyl acetate extract of nettle (Urtica dioica) and dandelion (Taraxacum officinale). J Appl Pharm Sci. 2013;3:96-9.

33. Jaswir I, Octavianti F, Hendri R, Khatib EA. Oxidative behaviour of four Malaysian edible plant extracts in model and food oil systems. J Med Plants Res. 2012;6:1556-61.

34. Shu-Yao T, Yu-Ching H, Hsiang-Yu L, Fu-Kuei H, Chun-Ping L. Comparison of the effect of Pleurotus citrinopileatus extract and vitamin $\mathrm{E}$ on the stabilization properties of camellia oil. J Therm Anal Calorim. 2017;130:1281-92. https://doi.org/10.1007/ s10973-017-64230.

35. Kozłowska M, Żbikowska A, Gruczyńska E, Żontała K, Półtorak A. Effects of spice extracts on lipid fraction oxidative stability of cookies investigated by DSC. J Therm Anal Calorim. 2014;118:1697-705.

36. Tumbas Šaponjac V, Cetković G, Canadanović-Brunet J, Pajin B, Djilas S, Petrović J, Lončarević I, Stajčić S. Sour cherry pomace extract encapsulated in whey and soy proteins: Incorporation in cookies. Food Chem. 2016;207:27-33.

37. Turan S. Effects of some plant extracts on the oxidative stability of canola oil and its purified triacylglycerols. J Food Qual. 2014;37:247-58.

38. Grajzer M, Prescha A, Korzonek K, Wojakowska A, Dziadas M, Kulma A, Grajeta H. Characteristics of rose hip (Rosa canina L.) cold-pressed oil and its oxidative stability studied by the differential scanning calorimetry method. Food Chem. 2015;188:459-66.

39. Litwinienko G. Autooxidation of unsaturated fatty acids and their esters. J Therm Anal Calorim. 2001;65:639-46.

40. Mahmood N, Tamanna N. Food processing and Maillard reaction products: effect on human health and nutrition. Int J Food Sci. 2015. https://doi.org/10.1155/2015/526762.

41. Li H, Fan YW, Li J, Tang L, Hu JN, Deng ZY. Evaluating and predicting the oxidative stability of vegetable oils with different fatty acid compositions. J Food Sci. 2013;78:H633-41. https:// doi.org/10.1111/1750-3841.12089. 